Laurentius Rumokoy et al./Animal Production. 18(2):94-101, May 2016

Accredited by DGHE No. 81/DIKTI/Kep./2011. ISSN 1411-2027

\title{
The Effects of Colostrum Immunoglobulin on Strongyloides Infection in Mice
}

\author{
Laurentius Rumokoy ${ }^{1 *}$, Jimmy Posangi ${ }^{2}$, Santi Turangan ${ }^{1}$, Ning Irianti ${ }^{3}$, Wisje Lusia Toar ${ }^{1}$, Julio Lopez Aban ${ }^{4}$ \\ ${ }^{1}$ Department of Nutrition and Feed Sciences, Faculty of Animal Husbandry, Sam Ratulangi University, Jln Kampus \\ Unsrat, Manado 95115, Indonesia \\ ${ }^{2}$ Department of Medicine Pharmacology, Faculty of Medicine, Sam Ratulangi University, Jln Kampus Unsrat, Manado \\ 95115, Indonesia \\ ${ }^{3}$ Faculty of Animal Husbandry, University of Jenderal Soedirman, Jln. dr Soeparno Purwokerto, 53123 Indonesia. \\ ${ }^{4}$ Area of Parasitology, Faculty of Pharmacy, University of Salamanca. Avda Ldo Mendez Nieto, 37007. Salamanca, Spain \\ Corresponding author email: rumokoy@msn.com
}

\begin{abstract}
This experiment was conducted to determine the effects of bovine colostrum IgG on mice infected with Larvae of Strongyloides venezuelensis (L3Sv). This experiment was a 2X2 factorial arrangement including two level of colostrum immunoglobulin-Gand two level of endostatine. The parameters were fecal eggs and number of female adult in the gut. The data were statistically analyzed for the mean and standard deviation values, and the differences in treatment groups were subject to ANOVA, if the global differences were detected, a post-ANOVA with LSD test ensued. The development of female adult in the gut, for each group, was performed using Spearman's rho test. Results showed that colostrum immunoglobulin-G reduce very significantly $(P<0.001)$ the number of eggs per gram feces than in the groups of infected animals treated with endostatine as well as in the mice injected with 3000 L3Vs only. While the reduction of female larvae was significant obtained $(P<0.05)$ in colostrum treatment $(L 3 S v+$ colostrum IgG) in comparison with endostatine. It was concluded that the supplementation of immunogobuline-G through the animal digestive system hadpositively control the Strongyloidesvenezuelensis parasite infection. This result provides aninsight to utilize IgG colostrum in animal husbandry to overcome the threat of parasitic worms infection.
\end{abstract}

Key words: Immunoglobulin-G, colostrum, intestine, parasite, animal husbandry

Abstrak: Penelitian ini bertujuan untuk mengkaji pengaruh IgG colostrum terhadap infeksi larva Strongyloidesvenezuelenensis (L3Sv) melalui suatu model eksperimen menggunakan tikus sebagai hewan percobaan. Penelitian ini disusun secara faktorial $2 \times 2$ yaitu faktor dua level IgG kolostrum dan dua level endostatine sebagai pembanding. Parameter yang digunakan adalah kuantitas telur cacing fekal dan larva betina parasit dalam usus. Dalam eksperimen ini menggunakan tikus yang semuanya diinjeksi 3000 L3Vs. Data yang diperoleh dianalisis secara statistik untuk rata-rata, standar deviasi dan dilakukan uji perbandingan antar kelompok dengan ANOVA dan dilanjutkan dengan uji LSD. Perkembangan jumlah larva betina dalam usus dari setiap kelompok treatment dianalisis menggunakan uji Spearman rho. Hasil penelitian menunjukkan bahwa immunoglobulin-G (IgG) kolostrum mampu menurunkan secara sangat siknifikan $(P<0.001)$ jumlah telur parasite per gram feces pada hewan percobaan dibandingkan endostatin, maupun hewan yang tidak mendapat perlakuan IgG dan endostatin sama sekali. Penurunan larva pada perlakuan IgG kolostrum berbeda nyata $(\mathrm{P}<0.05)$ dibandingkan dengan dua kelompok pembanding lainnya. Dapat disimpulkan bahwa suplementasi IgG kolostrum melalui sistem saluran pencernaan hewan memberi pengaruh positif untuk mengontrol infeksi parasit Strongyloides venezuelensis. Hasil penelitian ini memberi ide untuk menerapkan penggunaan IgG kolostrum dalam peternakan untuk mengatasi ancaman infeksi cacing.

Kata kunci: Immunoglobulin-G, kolostrum, usus, parasit, peternakan

\section{Introduction}

The threat of death in young ruminant animal characterized with extensive farms in rural areas is often caused by a parasite and or pathogenic microbe agent (Pfukenyi et al., 2007).Furthermore Nath et al. (2013) showed that Strongyloidesis a genus of parasitic nematode that often leads serious menace in livestock under traditional maintenance with 
poor hygiene. In connection with the countermeasures to this kind of infection, various synthetic drug has long been used especially to tackle problems in mammalian livestock, on the other hand it is also well known that certain drug residue can be very harmful for the animal production consumer (Panic et al., 2014). To date, very limited scientific information is available on the benefits natural resource of colostrum IgG in overcoming worm parasite infection (Rumokoy and Toar, 2014). It encourages a research to find the extent of IgG colostrum effect as a new strategy to overcome the animals infected with Strongyloides.

Livestock under traditional maintenance are easily susceptible to disease caused by parasites and or other pathogen agents. A study conducted by Nonga and Paulo(2015) indicated that $52 \%$ of parasites were Strongyloides. A potential alternative to overcome this problem of Strongyloides infection is to increase the immunity by empowering immune globuline-G because if neonates consume the colostrum, IgG will get immunity improvement against pathogen agent ex-uthero (Rumokoy and Toar, 2014). The cheap source of immunoglobuline-G (IgG) a is colostrum substances. In colostrum, the concentration of immunoglobulins is particularly high, with IgG being the major immunoglobulin class present in ruminant milk (Stelwagen et al., 2009).The good quality colostrum contains no less than $60 \mathrm{gr} \mathrm{lg} / \mathrm{L}$ (Drogoul et al., 2008) depends on varied factors including feed nutrient consumed (Mann et al., 2016) and environmental condition (Cabral et al., 2016).Three isotypes of $\mathrm{lg}$ found in colostrums are IgG, IgM, IgA. The most important Ig level in colostrum is IgG (Jacques, 2012). Toullec et al. (2001), reported that in a first milking cow's colostrum, Ig represent approximately $50 \%$ of total protein, IgG $88 \%$ of total Ig and IgG1 $95 \%$ of total IgG.

Neonate losses are very important in the mammalian livestock due to the parasite and pathogen agents (Mezo et al., 2007). Poulsen et al. (2010) reported that most of these neonate losses were due to infectious diseases included the parasites in conjunction with failure of passive transfer (FPT) that has been acknowledged as a major cause of neonatal disease in the world especially in the rural community. On the other hand, the infection of dangerous helminthes in the world become an important health problem in animal farm or domestics. Individual infections acquired through intact skin penetration by larvae filariform during contact with soil contaminated with feces or other material infected. Larvae of Strongyloidespapilus could enter the circulation and hematogenously carried to the lungs, where they enter the alveolar space (Dimitrijevic et al., 2012). It is necessary to find a solution scientifically, which can be obtained and developed from local natural resources to address the existing problems, especially those located in the tropical humid areas as in Indonesia.

The empowerment of natural resources for the purpose to manage these conditions such as parasitic infections can be reached by using bioactive materials like immunoglobulin-G obtained from mammalian maternal, for example cows (Cabral et al., 2016) and horses (Drogoul et al., 2008; Rumokoy and Toar, 2014).Worm infections in animal farm can cause significant economic loss (Alnakip et al., 2014). This loss is very important in the new born: a review on a large number of animals showed that about $12 \%$ of the foals died before weaning, half occurred on the first week after birth (Kalinbacak et al 2005). According to Stepek et al., (2006) this zoonosis parasites are particularly prevalent in rural areas of developing countries, where animals are often found living alongside humans in conditions of overcrowding, poor socio-economy and poor sanitation and hygiene, and there is frequently insufficient medical care and veterinary services and an unawareness of zoonotic diseases. There are many different causes of parasitic infection 
in animals or livestock, particularly young animal that raise animal mortality rate. The significance of FPT has been acknowledged the major cause of neonatal disease. The immune system of the new born uses various cells, cell surface receptors and signaling pathways to trigger an efficient host defense (Medzhitov, 2009).

In tackling such problems in young animals, passive transfer can be an alternative treatment with either colostrum replacer or immunoglobulin-G lyophilized (Rumokoy and Toar, 2014). Simultaneously, Swan et al., (2007) showed that passive transfer of IgG and preweaning health in newborn calves fed a commercially available plasma-derived colostrum replacement (CR) product or maternal colostrum may have had an opportunity against the pathogenic agent. Accordingly, William et al. (2014) and Priestley et al. (2013) pointed that passive transfer of antibody using colostrum replacement is a good choice because it contains nutrients and high level of IgG. Thus, many elements of mineral, vitamins, lipids, glucose and protein are available in the colostrum. Immunoglobulin-G is the most important level among other proteins globular in colostrum secretion. However, the study of the passive transfer of maternal antibody has poorly studied although very important in the management of livestock, especially where ecologically, the diseases are easily spread to cattle (Garnier, 2011). Endostatin function in generally is to induce microvascular endothelial cells apoptosis and inhibit endothelial proliferation (Zatterstrom et al 2000), and to decrease both egg per gram of feces and number of larvae from lung tissue (Shariati et al., 2010).

The objective of this study was to determine the effects of IgG colostrum on animal infected with Larvae of Strongyloides venezuelensis (L3Sv)through a model of experiment by supplementing colostrum IgG through drinking water compared to endostatine injection in mice and to the infected animal without endostatine.

\section{Materials and Method}

\section{Animal}

A total of 24 female CD1 mice, aging sixweek with body weight 20-27 g were used (Charles River Laboratories, Barcelona, Spain). Mice were housed in standard polycarbonate cages and placed in humidity and temperature controlled environment with a 12-hours photoperiod. The nutrients composition of the diets manufactured by Envigo Company, as shown in table 1 . The animals received water and feed ad libitum in the Experimental Animal Service of the University of Salamanca, Salamanca, Spain. The experiments of this work complied with current European Union law on animal experimentation.

Table 1. Nutritional Composition of the Diets

\begin{tabular}{lcc}
\hline $\begin{array}{l}\text { Nutrient and } \\
\text { Energy Values }\end{array}$ & Unit & Quantity \\
\hline Crude Protein & $\%$ & 22.5 \\
Fat & $\%$ & 5.2 \\
Crude Fiber & $\%$ & 42.7 \\
Carbohydrate & $\%$ & 3.7 \\
Neutral & $\%$ & 11.7 \\
Detergent Fiber & & 6.9 \\
Ash & $\%$ & $3.1(13.0)$ \\
Energy density & $\mathrm{Kcal} / \mathrm{g}$ & \\
Calories from & $(\mathrm{kJ} / \mathrm{g})$ & 29 \\
Protein & $\%$ & 15 \\
Calories from Fat & $\%$ & 56 \\
Calories from & $\%$ & 1.2 \\
Carbohydrate & & 1 \\
Calcium & $\%$ & \\
Phosphorus & $\%$ & \\
\hline
\end{tabular}

\section{Parasite}

The parasites were Strongyloides venezuelensis. Filariform infective larvae (L3) were obtained from a strain used in the Department of Parasitology, University of Minas Gerais, Belo Horizonte, Brazil, and their life cycle was maintained by serial passages in 4week-old male wistar rats. Feces were cultured 
in polyethylene urine sample recipients with vermiculite, mixed with distilled water for 3-7 days, $90 \% \mathrm{RH}$ at $28 \stackrel{\circ}{\circ}$.

\section{Experimental design}

Twenty four female mice housed in Center of Animal Research, Salamanca University were allotted to a $2 \times 2$ completely randomized factorial design, including two levels of colostrum immunoglobulin-G and two level of endostatine. The parameters were fecal eggs and number of female adult in the gut. The data were statistically analyzed for the mean and standard deviation values, and the differences in treatment groups were subject to ANOVA, if the global differences were detected, then a post-ANOVA was tested using the LSD test. The development of female adult in the gut, for each group, were performed using the Spearman's rho test. All experiment animals were maintained in this research center. The bovine colostrum IgG replacer was obtained through the laboratory of Parasitology USAL. The larvae was suspended at a concentration of $3 \times 10^{5} / \mathrm{mL}$ in PBS. The effect IgG by comparing with the endostatine effect was evaluated in three group of mice: Group A (L3Sv) was infected mice with 3000 L3 of Strongyloides venezuelensis (L3Sv)per animal; Group B (L3S+endostatine)constituted of mice L3SV infected treated with a ratio of $2 \mathrm{mg}$ endostatine in one $\mathrm{kg}$ of body weight. This endostatine was used as a parasite inhibitor. The injection was only performed at the first day experiment. Group C (L3Sv+lgG) received drinking water added with IgG 2 gr/L water. Egg output per gram of feces (EPG) was recorded on day 5,6 and 7 post infection (PI) and parthenogenetic females from the gut.

\section{Parasitological technique}

This stage applied McMaster technique in all treatment groups in comparison with control in triplicate. In the necropsy, the small intestine was removed (as shown in figure 1).

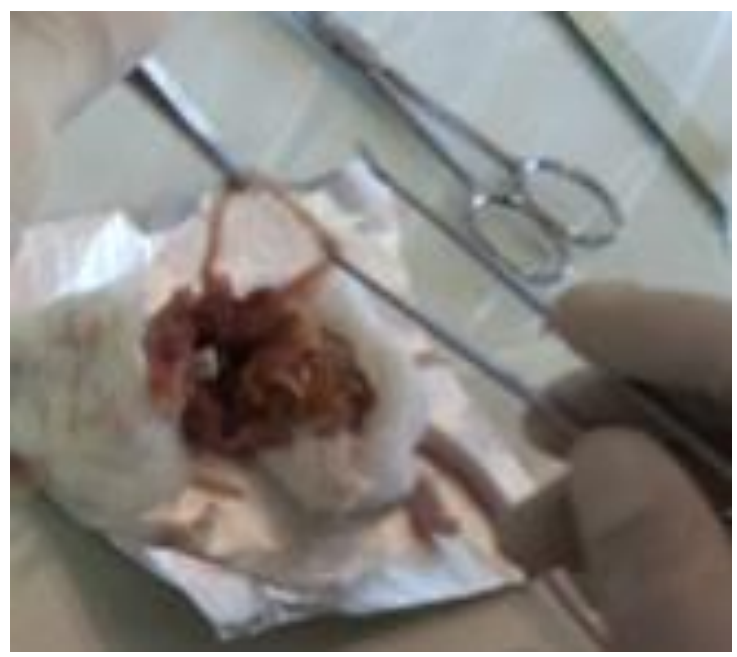

Figure 1. In the necropsy of experiment animal, small intestine was removed

Upon removing, the intestine washed, cut open longitudinally, and incubated in PBS for 4 hours at $37 \circ \mathrm{C}$, and the adult worms were collected and counted. Percentage of egg reduction was calculated using the formula (mean of infected mice group - mean of treated mice group) $\times 100 /$ mean of infected mice group.

\section{Statistical analysis}

The results of fecal eggs counts were statistically analyzed by ANOVA, if the global differences were detected then a post-ANOVA using LSD test ensued. The development of femaleadult in the gut for each group was performed using Spearman's rho test.

\section{Results and Discussion}

\section{Eggs recovering}

The eggs output observed is shown in Figure 1.Theexperimentaltreatmentresponse, to the number of eggs per gram (EPG) of the animals tested, sorted respectively according to the level of the quantity of eggs. In this study we found that colostrum immunoglobulin- $G$ highly significantly $(P<0.001)$ reduced the number of eggs per gram feces compared to that in control group of infected animals treated with endostatine and in the mice injected with 3000 L3Vs only. The increasing EGP in the feces was significant observed in day 5 to day 7 . 

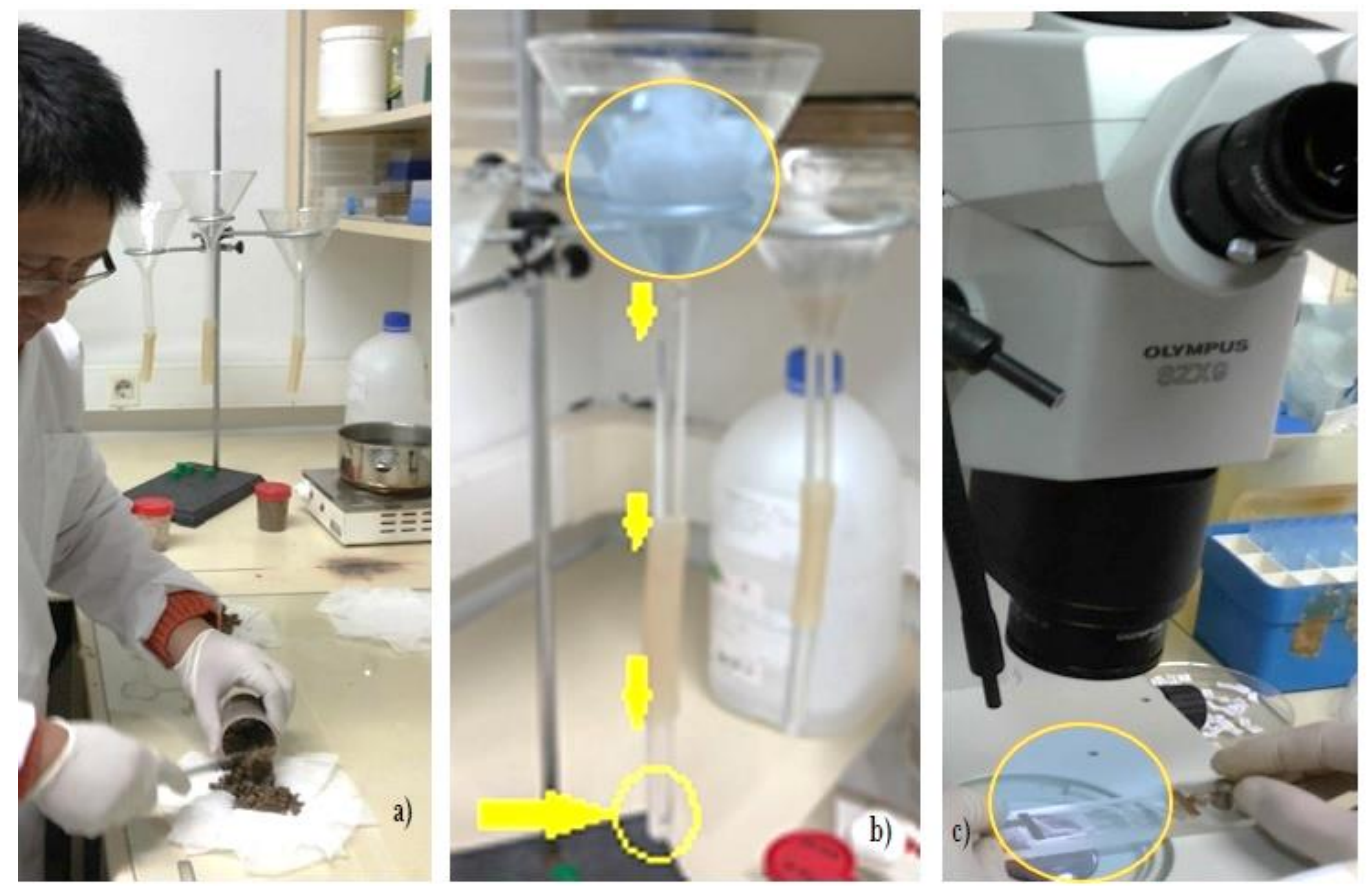

Figure 2. Parasite counting: a. feces sample was prepared for larva quantification, b. adult worm collecting by gravitation, c. larva counting with light microscopy

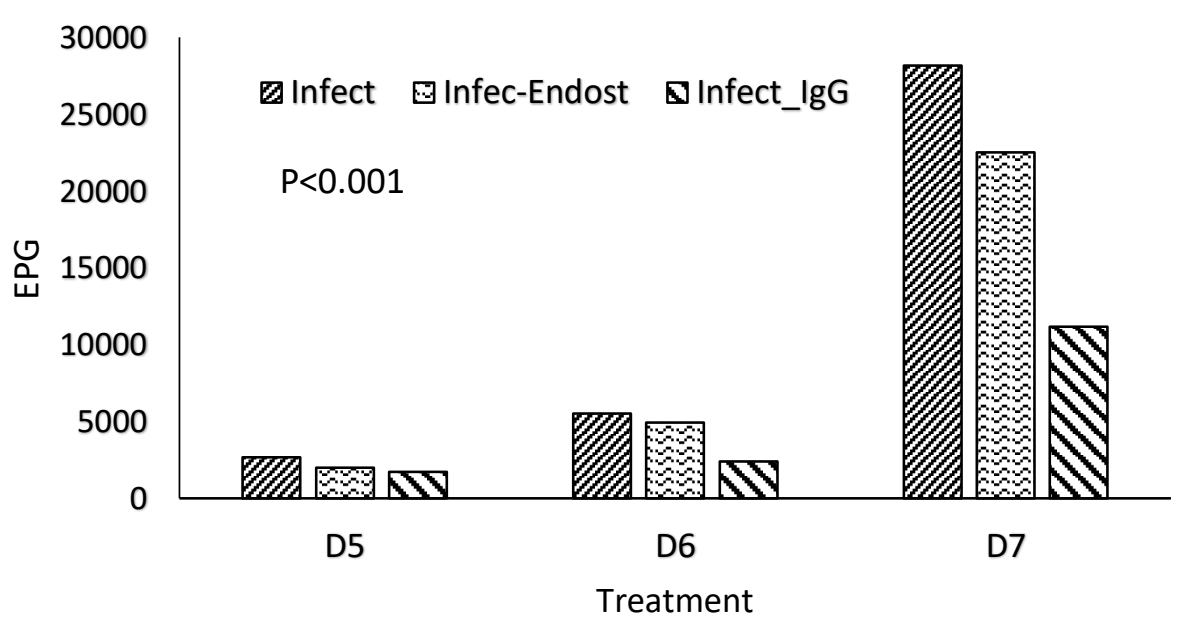

Figure 3. The number of eggs per gram (EPG) in feces of animals post infection. The colostrum IgG reduced the EPG very significantly $(P<0.001)$ compared to control and endostatin at three days $(D)$ of observation D5, D6 and D7. Note: Infec = infection by L3Sv injection; Infect-Endost = infection by L3Sv and endostatine injection; and Infect_IgG = infection by L3Sv injection plus colostrum IgG addition in drink water.

Furthermore the results showed that the numbers of egg in the feces of animals treated with endostatine and animals treated with IgG was significantly different $(P>0.05)$. The IgG of colostrums, useful for the neonates to defense against the parasite and pathogenic microbesex-uthero (Rumokoy and Toar, 2014). This results can be connected to the efforts for breaking down the worm infection as one of the major nematode infections of mammalian in tropical and subtropical regions (Obonyo et al., 2013).

The use of colostrum IgG has advantages compared to others substance because it is safe for animal health. If applied to the mammalian livestock such as horses, cows, goats, pigs, 
these substances (IgG colostrum) might not adversely affect the health of livestock products consumer. Furthermore, IgG colostrum can be obtained easily from horse colostrum and or livestock mammals such as cows and goats, so easily applied in rural areas to anticipate such endo-parasites problems. In fact, the price of anti-strongyloides products such as endostatine is costly and not readily available in the markets.

\section{Females recovering from the gut}

We evaluated the effects ofcolostrum immunoglobulinsand endostatin administration in mice infected with 3000 L3 S. Venezuelensis. The average number of parasiteS. venezuelensis females from the gut was 61 in the group of infected mice, 41 in the group of mice treated with endostatin; and the lowest was 18,5 in the group of mice treated with colostrum IgG.

The number of female adult in intestin of mice infected without endostatin nor IgG compared to mice given endostatin or IgG was statistically difference $(P<0.05)$. While the differentamount of larvae between the mice treated with endostatin andthose with IgG colostral was not significant differences $(P>0.05)$. This positive respons of IgG compared to other controls group was associated with the function of colostrum antibodies which are thought to coat the mucosal surfaces lining the gut and prevent invasion by pathogenic organisms (Hurley and Theil, 2011). In addition, the supply of colostrum IgG from other parent as passive transport of antibodies serves to overcome the problems of microbial pathogenic and parasitic infections (Werem et al., 2001). This response has a similar impact as reported by Poulsen et al., (2010) that ingestion and absorption of the immunologic substances in colostrum by neonatal could reduce morbidity and mortality rates and have a positive influence on the future productivity.

The risk of parasite infection is often correlated to the rapid environmental change and therefore an anticipation against this phenomena could be implemented by empowering the function of colostrum through a passive transfer immunity (Jolles et al., 2015). The significant effect to reduce the female of SL3Vs in the gut along the observation of our experiment seems related to Perkens and Wagner (2015) that the immune response of some adaptive immune parameters, such as immunoglobin (Ig)G1, IgG3, IgG5 and IgA antibodies starts before or at birth and matures within 3 months of life. Furthermore the finding articulated that other antibody responses, such as IgG4, IgG7 and IgE production, slowly develop within the first year of life until they reach adult levels. This statements become one of scientific reasons to apply the colostrum IgG substance against the parasite threat to the neonates.

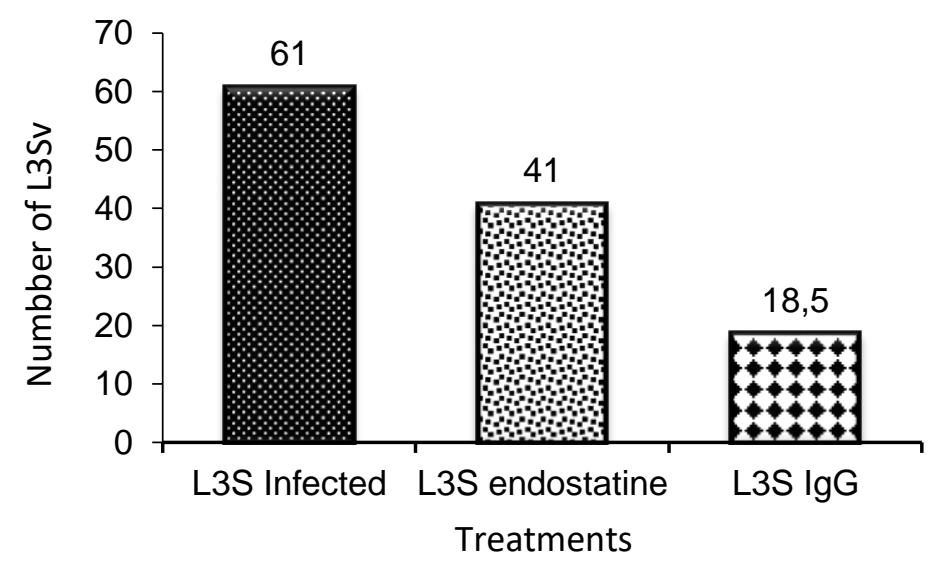

Figure 4. The lowest number of L3Sv in gut was recorded in animals treated with L3S + IgG 


\section{Conclusions}

Supplementation of colostrum IgG through drinking water can strongly reduce the EPG post infection and also the larvae in animals infected with of parasite S.venezuelensis. This ability of colostrum to reduce the parasite is more powerful than endostatine action to inhibit the number of eggs and larvae of the infected animal with Strongyloides.

\section{Acknowledgment}

The authors were grateful to the Ministry of Research, Technology and Higher Education of Republic of Indonesia for financial support for the experiment under an international collaboration with the University of Salamanca Spain. Equal gratitude is addressed to the Director of CIETUS of University of Salamanca in Spain for the permit to us Indonesian researchers to conduct research in their Laboratory of Parasitology and Immunology.

\section{References}

Alnakip EM, M Quintela-Baluja, K Böhme, I Fernández-No, S Caamaño-Antelo, P Calo-Mata P and J Barros-Velázquez. 2014. The Immunology of Mammary Gland of Dairy Ruminants between Healthy and Inflammatory Conditions. J. Vet. Med. 2014:1-31.

Cabral RG, CE Chapman, KM Aragona, E Clark and M Lunak, PS Erickson. 2016. Predicting colostrum quality from performance in the previous lactation and environmental changes. J. Dairy Sci. 99(5):4048 - 4055.

Dimitrijevic B, S Borozan, S Katić-Radivojević and S Stojanović. 2012. Vet Parasitol. Effects of infection intensity with Strongyloides papillosus and albendazole treatment on development of oxidative/nitrosative stress in sheep. 25 (186):364-375.

Drogoul C, F Clément, M Ventrop, MC Curadi and M Orlandi. 2008 Equine passive immune transfer trough colostrum. Proceedings of the 4th European Equine Nutrition \& Health Congress April. 18-19, 2008.

Garnier R. 2011. Ecologie evolutive de la transmission maternelle d'anticorp. Montpellier
SubAgro.Centre International d'Etudes en Sciences Agronomiques. PhD Dissertation, 15 Décembre 2011.

Hurley WL and PK Theil. 2011. Perspectives on Immunoglobulins in Colostrum and Milk. Nutrients. 3(4):442-474.

Jacques S. 2012.Succédanés du colostrum et transfert d'immunité passive chez le veau nouveau-né. Thèse d'exercice, Médecine vétérinaire, Ecole Nationale Vétérinaire de Toulouse - ENVT.

Jolles AE, R Brianna, Beechler and BP Dolan. 2015. Beyond mice and men: Environmental change, immunity and infections in wild ungulates. Parasite Immunol. 37(5):255-266.

Kalinbacak A, M Guzel and I Altintas. 2005.Incidence of failure of immune passive transfer (FPT) in horoughbred foals - Interest of a rapid diagnosis for FPT. Revue Méd Vét. 156(3):163-165.

Mann S, FAL Yepes, TR Overton, AL Lock, SV Lamb, JJ Wakshlag and DV Nydam. 2016. Effect of dry period dietary energy level in dairy cattle on volume, concentrations of immunoglobulin G, insulin, and fatty acid composition of colostrum. J. Dairy Sci. 99(2):1515 - 1526.

Medzhitov R. 2007 Recognition of microorganisms and activation of the immune response. J. Nature. 2007. 18:819-826

Mezo AR,KA McDonnell, CAT Hehir, SC Low, VJ Palombella, JM Stattel, GD Kamphaus, C Fraley, Y Zhang and JA Dumont.2008. Reduction of IgG in nonhuman primates by a peptide antagonist of the neonatal Fc receptor FcRn. Proc PNAS 105(7):2337-2342.

Nath TC, MJU Bhuiyan, and MS Alam. 2013. Prevalence of gastro-intestinal parasites of calves in Mirsarai Upazilla of Chittagong district of Bangladesh. Bang. J. Anim. Sci. 2013. 42(2):139142.

Nonga HE and N Paulo. 2015. Prevalence and intensity of gastrointestinal parasites in slaughter pigs at Sanawari slaughter slab in Arusha, Tanzania. Livestock Research for Rural Development. 27(1).

Obonyo FO, N Maingi, SM Githigia andCJ Ng'ang'a. 2013. Farming practices and risk factors for transmission of helminths of free range pigs in Homabay District, Kenya. Livestock Research for Rural Development. 25 (3).

Panic G, U Duthaler, B Speich and J Keiser. 2014. Repurposing drugs for the treatment and control of helminth infections. International Journal for Parasitology: Drugs and Drug Resistance 4 (2014):185-200.

Perkins GS and B Wagner. 2015. The development of equine immunity: Current knowledge on 
immunology in the young horse. Equine Vet. Journal. 17(3):369-460.

Pfukenyi DM, S Mukaratirwa, AL Willingham, and J Monrad. 2007. Epidemiological studies of parasitic gastrointestinal nematodes, cestodes and coccidia infections in cattle in the highveld and lowveld communal grazing areas of Zimbabwe. Onderstepoort Journal of Veterinary Research. 74:129-142.

Poulsen KP,LF Andrea, TC Michael and SM McGuirk. 2010. Comparison of passive transfer of immunity in neonatal dairy calves fed colostrum or bovine serum-based colostrum replacement and colostrum supplement products. J Am Vet Med Assoc. 15; 237(8):949-954.

Priestley D, JH Bittar, L Ibarbia, CA Risco and KN Galvão. 2013. Effect of feeding maternal colostrum or plasma-derived or colostrumderived colostrum replacer on passive transfer of immunity, health, and performance of preweaning heifer calves. J. Dairy Sci. 96:3247-3256

Rumokoy L,and WL Toar. 2014. The equine colostrums of milk treatment against pathogenic agent. Scientific Papers Series D. Animal Sciencevol. 52:174-177.

Shariati F, JL Péres-Arrelano, J López-Abán, AME Behairy and A Muro. 2010. Role of angiogenic factors in acute experimental Strongyloides. venezuelensis infection. Parasite Immunology. 32:430-439

Stelwagen K, E Carpenter, B Haigh, A Hodgkinson, and TT Wheeler. 2009. Immune components of bovine colostrum andmilk. J. Anim. Sci. 87 (13 suppl.): 3-9.

Stepek G, DJ Buttle, IR Duce andJM Behnke. 2006Human gastrointestinal nematode infections: are new control methods required? Int. J. Exp. Pathol. 87(5):325-341.

Swan H, S Godden, R Bey, S Wells, J Fetrow and H Chester-Jones. 2007. Passive Transfer of Immunoglobulin $\mathrm{G}$ and Preweaning Health in Holstein Calves Fed a Commercial Colostrum Replacer. J. Dairy Sci. 90:3857-3866.

Toullec R, JP Lallés, JF Grongnet andD Levieux. 2001. Digestion of colostrum by the preruminant calf: digestibility and origin of undigested protein fractions in ileal digesta. INRA, EDP Sciences. Lait 81:443-454.

Werem A, M Strabel, JF Grongnet and M Piot. 2001 Immunoglobulin $G$ absorption from pooled maternal colostrum, commercial powder and freeze-dried colostrum by newborn calves. Anim. Res. 50:315-323.

Williams DR, P Pithua, A Garcia, J Champagne, DM Haines and SS Aly. 2014. Effect of Three Colostrum Diets on Passive Transfer of Immunity and Preweaning Health in Calves on a California Dairy following Colostrum Management Training. Vet Med Int. 2014:1 - 9.

Zatterstrom UK, U Felbor, N Fukai and BJ Olsen. 2000. Collagen XVIII/ Endostatin structure and functional role in angiogenesis. Cell Structure and Function. 25:97-101. 